\title{
Vertaisarvioinnin uusin suunta on avoimuus
}

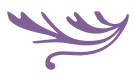

Lisää vastuullisuutta julkaisuprosessiin, arvostusta refereille. Avoin vertaisarviointi muuttaa tutkijan työtä ja tiedejulkaisemisen käytäntöjä.

TOIMITUSKUNTA LÄHETTI TERVEISIÄ: "Onneksi olkoon, artikkelisi on hyväksytty Aikuiskasvatuksen julkaisuprosessiin.”

Seuraavana vuorossa on vertaisarviointi, jossa selvitetään, ylittääkö teksti tiedelehden julkaisukynnyksen. Vertaisarvioijat eli refereet, useimmiten kaksi aiheeseen eri kanteilta perehtynyttä tutkijaa, arvioivat muun muassa tutkimusaiheen merkityksellisyyttä, tutkimusasetelmaa, lähteitä, argumentoinnin vakuuttavuutta ja luettavuutta kaikkea, mikä vaikuttaa artikkelin laatuun.

Yleensä vertaisarviointi tehdään siten, että kirjoittaja ei tiedä arvioijaa eikä arvioija tiedä kirjoittajaa. Aikuiskasvatus noudattaa astetta ankarampaa käytäntöä: myös toimituskunta arvioi tarjotun käsikirjoituksen sokkona ja hylkää tai ottaa sen refereeprosessiin tietämättä tekijää.

Avoimen tieteen vanavedessä Suomenkin on saavuttamassa innovaatio, jossa nimettömyydestä luovutaan kokonaan. Avoimessa vertaisarvioinnissa sekä tekijä että referee tuntevat toisensa nimeltä. Arviot saatetaan julkaista artikkelin yhteydessä.
Äärimmilleen vietynä kuka tahansa pääsee kommentoimaan artikkelia verkossa kuten iltapäivälehden uutista.

\section{VAROVAISEN MYÖNTEISELLÄ KANNALLA}

Vertaisarvioinnin merkitys tiedelehden julkaisuprosessissa on kyseenalaistamaton. Avoin vertaisarviointi muuttaa julkaisuprosessia ja sen myötä niin tekijän ja toimituskunnan kuin vertaisarvioijien työtä. Mutta parantaako se tutkimuksen laatua?

”Ihmettelen, miten vähän avoimesta vertaisarvioinnista mutta myös vertaisarvioinnista ylipäätään on puhuttu, kun ajattelee, miten keskeinen merkitys sillä on akateemisessa maailmassa”, sanoo kirjallisuudentutkija Riitta Jytilä Turun yliopistosta.

Hän kuuluu työryhmään, joka selvitti tiedejulkaisemisen kentän näkemyksiä avoimesta vertaisarvioinnista. Verkkokyselyyn saatiin 108 vastausta kirjoittajilta, refereiltä, tiedelehtien toimittajilta ja lukijoilta. Lisäksi haastateltiin sähköpostitse kahdeksaa 


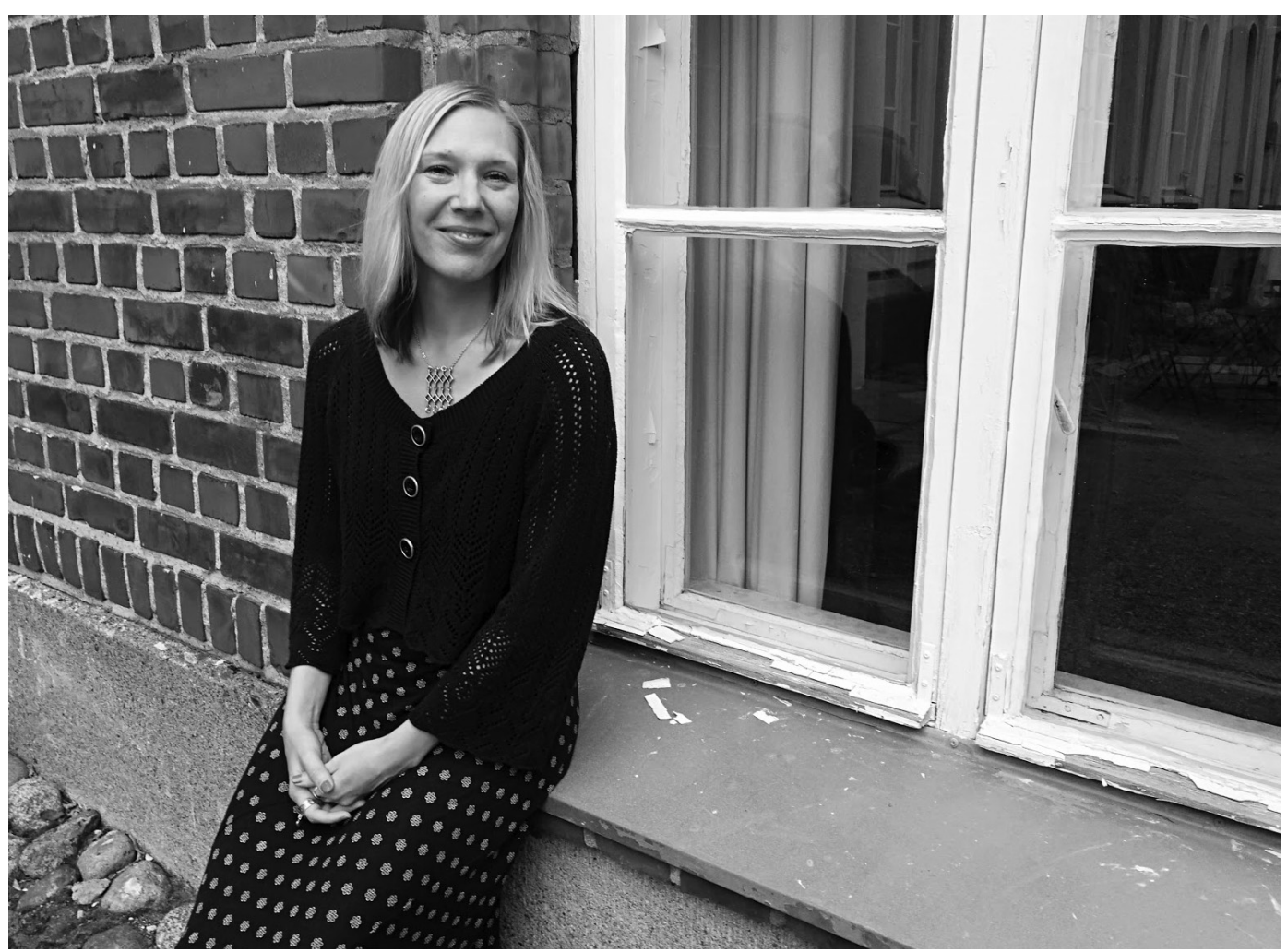

"Avointa vertaisarviointia koskevalla selvityksellä lisätään ymmärrystä ilmiöstä ja vahvistetaan tiedekentän omaa ääntä suhteessa kansainvälisiin innovaatioihin", tutkija Riitta Jytilä sanoo.

vertaisarviointitunnusta käyttävää kirjankustantajaa.

Selvityksen perusteella tiedejulkaisemisen kenttä suhtautuu ilmiöön varovaisen myönteisesti, mutta suuria paineita ei käytäntöjen muuttamiseen ole. Tyytyväisimpiä sokkoarviointiin ovat julkaisujen toimittajat, joista yli 70 prosenttia kannattaa nykyistä käytäntöä.

Monet ovat odottavalla kannalla: ensin on saatava sekä tutkittua tietoa että kokemuksia. Selvityksen tekijät yllättyivät siitä, miten hanakasti jotkut puolustivat nykykäytäntöjä.

"Selvitys koettiin käytäntöä ohjaavaksi, vaikka tarkoituksemme oli luoda työkalut, joiden avulla toimituksissa voidaan omaehtoisesti ottaa kantaa asiaan”, Jytilä sanoo.

\section{KOKO JULKAISUPROSESSI AUKI}

Miksi sitten omaksua uusi tapa, kun vanhakin toimii?

Ensinnäkin avoin vertaisarviointi lisää tutkimusprosessin läpinäkyvyyttä. Lukija saattaa artikkelia lukiessaan esimerkiksi kummastella, miksi tutkijat ovat täydentäneet aineistoaan, vaikka se ei tunnu tarpeelliselta - lausuntoa lukemalla selviää, että referee on näin vaatinut.

Toiseksi avoin vertaisarviointi tekee näkyväksi refereen työn. Hyvä arvioitsija kannustaa tutkijaa kirkastamaan ajatuksiaan, täydentämään aineistojaan ja tarkentamaan kysymyksiään.

”Nykyäänkin kirjoittamansa lausunnon voi kirjata ansioluetteloon, mutta näkyvästi se ei tutkijaa meritoi", Jytilä toteaa. 
Sitä paitsi lausunnonantajakin on arvioinnin kohteena. Arviointikulttuuri saattaa muuttua, kun lausunto on kirjoitettava julkiseksi. Nimettömyyden taakse ei voi piiloutua, eikä puolueellisuuteen, piikittelyyn tai henkilökohtaisuuksiin ole varaa.

Vastuullisuus korostuu avoimuuden myötä.

"Anonyymius on alun perin luotu suojaamaan tiettyjä asioita, kuten sukupuolta tai instituutiota, mutta se voi kääntyä itseään vastaan”, Riitta Jytilä tulkitsee.

Kaikkia vertaisarvioinnin pulmia avoimuus ei kuitenkaan ratkaise. Menetelmästä riippumatta tutkija joutuu toisinaan pähkäilemään keskenään ristiriitaisten lausuntojen kanssa. Eikä arvioitsija aina havaitse käsikirjoituksen virheitä, vaan ne ilmenevät vasta jälkikäteen. Avoimessakin arvioinnissa referee saattaa vitkastella lausuntonsa kanssa.

Entä löydetäänkö arvioijia, kun prosessi on yhä työläämpi ja lausunto päätyy julkisen arvostelun kohteeksi? Etenkin pienillä tieteenaloilla näin on jo nyt.

"Kaikki tutkijat eivät ole halukkaita toimimaan arvioijina, kun arviointi ei ole nimetöntä ja raportin kirjoittaminen vaatii toisenlaista ajattelua”, Riitta Jytilä pohtii.

\section{SITÄ SAA MITÄ TILAA}

Olipa arviointitapa ja tieteenala mikä hyvänsä, vertaisarvioinnin ohjeistus on olennainen. Mitä tarkemmat refereeohjeet, sitä hyödyllisempi palaute.

Parhaaseen tulokseen päästäkseen toimituskunnan kannattaa ohjeistaa arvioija kiinnittämään huomionsa olennaisiin seikkoihin ja korostaa, että hyödyllisin arvio on hengeltään rakentava. Refereepolitiikka on lisäksi syytä avata lehdessä tai sen verkkosivuilla.

Näin asia linjataan Aikuiskasvatuksessa:

"Arvioinnin tavoite on antaa kirjoittajalle ehdotuksia ja neuvoja artikkelin parantamiseksi. Hyödyllisintä on rehellinen, kriittinen, käytännöllinen ja kannustava palaute.”

Vastuullisuutta, läpinäkyvyyttä, arvostusta refereille. Avoimen vertaisarvioinnin lupaukset ovat kieltämättä houkuttelevia.

"Käytännössä avoimuudessa on monta astetta. Toimituskunnan kannattaa perehtyä ilmiöön, keskustella omista tarpeista ja tarvittaessa tarkistaa refereelinjauksiaan”, Riitta Jytilä kannustaa.

Hän painottaa, että yhtä, kaikille sopivaa patenttiratkaisua ei vertaisarvioinnissakaan ole. Tieteenaloilla on erilaisia kulttuureita, jotka on otettava huomioon, kun pohditaan uusia toimintatapoja. Tietoa pohdinnan tueksi on luvassa syksyn mittaan, kun selvitykseen perustuva raportti julkaistaan Tieteellisten seurain valtuuskunnan (TSV) verkkosivuilla. 


\section{Monta tapaa arvioida}

\section{Yksipuolinen sokkoarviointi (single-blind review)}

Artikkelin kirjoittaja ei tiedä arvioijan henkilöllisyyttä, mutta arvioija tietää kirjoittajan henkilöllisyyden. Yleisin tapa arvioida artikkelin tieteellistä laatua. Menettelyä sanotaan myös puoliavoimeksi arvioinniksi.

\section{Kaksoissokkoarviointi (double-blind review)}

Kumpikaan osapuoli ei tiedä toisen henkilöllisyyttä. Näin pyritään mahdollisimman puolueettomaan arviointiin. Varsinkin pienillä tieteenaloilla osapuolet saattavat kuitenkin tunnistaa toisensa. Tapa on yleisin humanistisilla ja yhteiskuntatieteellisillä aloilla.

\section{Avoin vertaisarviointi (open peer-review)}

Kirjoittaja ja referee tietävät toisensa. Avoimuudella pyritään välttämään sokkoarvioinnin pulmia. Jotkut tiedelehdet kertovat arvioijien henkilöllisyyden vain artikkelin kirjoittajalle, toiset julkaisevat arvioijien nimet lehdessä. On myös lehtiä, jotka julkaisevat myös arviointiraportit, jolloin arviointiprosessi avautuu lukijoille.

\section{Julkaisemisen jälkeinen arviointi (post-publication review)}

Lukijat saavat kommentoida artikkelia ja arvioida sitä esimerkiksi numeroin. Menetelmään voi kuulua myös tavallinen ennakkoarviointi. Etuna on laaja arvioijajoukko ja prosessin vuorovaikutteisuus.

\section{LÄHTEET}

Rossi, L. (2011). Vertaisarvioijan valta. Hybris 1/2011. http://hybrislehti.net/hybris-12011/vertaisarvioijan-valta (10.9.2018).

Jytilä, R., Koikkalainen, R., Laakso, M. \& Nykyri, S. (2018). Avointa vertaisarviointia koskevalle selvitykselle rahoitus. Informaatiotutkimus 1/2018. https://journal.fi/ inf/article/view/70172 (10.9.2018). 